PERSPEKTIF Volume XI No.3 Tahun 2006 Edisi Juli

\title{
RESTRUKTURISASI PEMBIAYAAN SEBAGAI SALAH SATU UPAYA PENANGANAN PEMBIAYAAN BERMASALAH
}

Oleh :

Trisadini Prasastinah Usanti

\begin{abstract}
Financing given by syaria banking always has potensial risk of repayment failure which causes non performing financing. Attemps from syaria banking to resolve non performing financing are principally the same with conventional banking. Those attemps are such as: financing restructure, collateral execution, through litigation, through board of arbitration national syaria, write off and hair cut
\end{abstract}

Keywords : Sharia Bank, Financing Restructure, Non Financing Performing

Didalam perekonomian suatu negara salah satu lembaga keuangan yang mempunyai nilai strategis adalah lembaga keuangan bank. Lembaga tersebut dimaksudkan sebagai perantara antara pihak-pihak yang mempunyai kelebihan dana dengan pihak-pihak yang kekurangan dana. Lembaga keuangan bank bergerak dalam kegiatan perkreditan, dan berbagai jasa yang diberikan bank melayani kebutuhan pembiayaan serta melancarkan mekanisme sistem pembayaran bagi semua faktor perekonomian.(Muhamad Djumhana, 1993:1)

Syariah Islam sebagai suatu syariah yang dibawa oleh rasul terakhir, mempunyai keunikan tersendiri. Syariah ini bukan saja menyeluruh atau komprehensif tetapi juga universal.
Karakter istimewa ini diperlukan sebab tidak akan ada syariah lain yang datang untuk menyempurnakannya. Syariah Islam merangkum seluruh aspek kehidupan, baik ritual (ibadah) maupun sosial (muamalah) dan dapat diterapkan dalam setiap waktu dan tempat sampai hari akhir nanti. (Muhammad Syafii Antonio, 2001: 4) Kebangkitan kembali nilai-nilai fundamental telah melahirkan Islamisasi sektor finansial dengan fokus bank bebas bunga (Free interest banking) atau secara luas dikenal dengan bank Islam (Islamic Banking). (Muhammad, 2005: 73)

Keberadaan perbankan syariah di Indonesia merupakan suatu perwujudan dari permintaan masyarakat yang membutuhkan suatu sistem perbankan alternatif yang menyediakan jasa 
perbankan yang sehat juga memenuhi prinsip-prinsip syariah. Perkembangan sistem keuangan syariah secara formal dimulai sejak diundangkannya Undangundang Nomor 7 Tahun 1992 tentang Perbankan (Lembaran Negara Tahun 1992 Nomor 31) sebagaimana diubah dengan Undang-undang Nomor 10 Tahun 1998 tentang Perubahan Undangundang Nomor 7 Tahun 1992 (Lembaran Negara Tahun 1998 Nomor 182) untuk selanjutnya disebut UU Perbankan. Keradaan bank syariah telah mendapatkan landasan hukum tersendiri yaitu sejak disahkan Undang-undang Nomer 21 Tahun 2008 Tentang Perbankan Syariah pada tanggal 16 Juli 2008, LNRI Tahun 2008 Nomor 94 (Selanjutnya disingkat dengan UU Perbankan Syariah).

Hal ini telah menunjukkan perkembangan yang cukup pesat dengan memberikan kesempatan yang lebih luas bagi perkembangan bank syariah yaitu dengan cara memberi kesempatan bagi bank umum konvesional untuk melakukan dual banking system dalam arti melakukan kegiatan konvesional bersamaan dengan kegiatan usaha berdasarkan prinsip syariah, yaitu dengan membuka kantor cabang syariah yang khusus melayani kegiatan perbankan syariah. Menurut Sutan Remy Sjahdeini "Perbankan Islam menjadi fenomena baru yang perkembangannya telah mengejutkan para pengamat perbankan konvensional. Bahkan bankbank besar dari negara non muslim telah pula memasuki pasar perbankan Islam dengan membuka Islamic window. Tidak kurang dari Citibank, Chase Manhanttan Bank, ANZ Bank dan Jardine Falming telah membuka Islamic window agar dapat berkiprah memberikan jasa perbankan Islam". (Sutan Remy Sjadeini, 2002: 1)

Bank syariah merupakan salah satu aplikasi dari sistem ekonomi syariah Islam yang merupakan bagian dari nilainilai dari ajaran Islam yang mengatur bidang perkonomian umat dan tidak terpisahkan dari aspek-aspek lain ajaran Islam yang komprehensif dan universal. Komprehensif berarti ajaran Islam merangkum seluruh aspek kehidupan, baik ritual maupun sosial kemasyarakatan termasuk bidang universal. Universal bermakna bahwa syariah Islam dapat diterapkan dalam setiap waktu dan tempat tanpa memandang ras, suku, golongan dan agama sesuai prinsip Islam sebagai "rahmatan lil alamin".

Fungsi Bank Syariah secara garis besar tidak berbeda dengan bank 
konvensional, yakni sebagai lembaga intermediasi (intermediary institution) yang mengerahkan dana dari masyarakat dan menyalurkan kembali dana-dana tersebut kepada masyarakat yang membutuhkan-nya dalam bentuk fasilitas pembiayaan. Perbedaan pokoknya terletak dalam jenis keuntungan yang diambil bank dari transaksi-transaksi yang dilakukannya. Bank Syariah melakukan kegiatan usahanya tidak berdasarkan bunga (interest fee), tetapi berdasarkan pada prinsip syariah yaitu prinsip pembagian keuntungan dan kerugian (profit and loss sharing atau PLS). (Sutan Remy Sjadeini, 1999: 1)

Ide dasar adanya bank syariah ini adalah upaya untuk menangkal sistem ribawi yang ada pada bank-bank konvensional sebagaimana kita saksikan dewasa ini. Sebab dalam perspektif Islam terhadap persoalan ini sudah jelas, yaitu Allah dengan jelas dan tegas mengharamkan riba. Keinginan ini dilandasi oleh suatu kesadaran untuk menerapkan Islam secara utuh dan total sebagaimana ditegaskan Allah SWT dalam surah Al-Baqarah ayat 208: "Hai orang-orang yang beriman, masuklah kamu ke dalam Islam secara keseluruhan, dan janganlah kamu turuti langkah-langkah syaitan. Sesungguhnya syaitan itu musuh yang nyata bagimu". Ayat tersebut dengan tegas mengingatkan bahwa selama kita menerapkan Islam secara parsial, kita akan mengalami keterpurukan duniawi dan kerugian ukhrowi. Hal ini sangat jelas karena Islam hanya diwujudkan dalam bentuk ritualisme ibadah.

Gagasan adanya lembaga perbankan yang beroperasi berdasarkan prinsip syariah berkaitan erat dengan gagasan terbentuknya suatu system ekonomi Islam. Gagasan berdirinya bank syariah ditingkat Internasional, muncul dalam konferensi Negara-negara Islam sedunia di Kuala Lumpur Malaysia. Pada tanggal 21 sampai dengan 27 April 1969, yang diikuti oleh 19 Negara peserta. (Sutan Remy Sjadeini, 1999: 5). Semula pembentukan bank syariah pada mulanya memang banyak diragukan. Pertama, banyak orang beranggapan bahwa system perbankan bebas bunga (Interest Free) adalah sesuatu yang tidak mungkin dan tidak lazim. Kedua, adanya pertanyaan tentang bagaimana Bank akan membiayai operasinya.(Sutan Remy Sjadeini:1999: 6) Dalam Syariah terdapat kewajiban bagi umat Islam untuk harus melaksanakan ketentuan dalam Al-Qur'an dan Al-Hadist. 
Sehingga dalam melakukan kegiatan ekonomi pun harus sesuai dengan Syariah. Dengan adanya larangan riba di dalam Al-Qur'an dan Al Hadist yang kemudian muncul bank syariah yang beroperasi berdasarkan system bagi hasil. Hal ini merupakan peluang bagi umat Islam untuk memanfaatkan jasa bank secara optimal.

Guna memahami perbankan syariah, maka pengkajian tentang riba merupakan hal yang penting. Istilah riba berasal dari akar kata r-b-w yang digunakan dalam Al Quran sebanyak duapuluh kali. Didalam AI Quran term riba dapat dipahami dalam delapan macam arti yaitu pertumbuhan (growing), peningkatan (increasing), bertambah (swelling), meningkat (rising), menjadi besar (being big), dan besar (great), dan juga digunakan dalam pengertian bukit kecil (hillock), walaupun istilah riba tampak dalam beberapa makna, namun dapat diambil satu pengertian umum yaitu meningkat (increase) baik menyangkut kualitas maupun kuatitasnya.( Abdullah Saeed, 1996:10)

Penolakan atas bunga yang dianggap riba memunculkan pertanyaan tentang apa yang dapat menggantikan mekanisme penerapan suku bunga dalam kerangka kerja perbankan Islam. Jika pembayaran dan penarikan bunga dilarang, bagaimana bank-bank Islam beroperasi?. Disinilah PLS masuk, menggantikan sistem bunga dengan sistem profit and loss sharing (bagi untung dan rugi) sebagai metode alokasi sumber daya. Meskipun banyak sekali bentuk kontrak dalam permodalan Islam, namun ada beberapa jenis transaksi yang penting: mudharabah (kontrak permodalan), musyarakah (kontrak kemitraan/partnership); dan metode mark up (penaikan harga). (Mervyn Lewis and Latifa Algaoud,2001: 13) Menurut Muhammad Nejatullah Siddiqi, pilar dari operasional perbankan Islam adalah berdasarkan pada Shirkah (partnership) dan mudarabah (profit sharing) aktivitas investasi dalam bank Islam didasarkan pada dua konsep yang legal yaitu mudharabah dan musyarakah, sebagai alternatif dalam menerapkan sistem bagi hasil (profit and loss sharing/PLS) . Teori ini menyatakan bahwa bank Islam akan memberikan sumber pembiayaan (finansial) yang luas kepada peminjam (debitur) berdasarkan atas bagi resiko (baik menyangkut keuntungan maupun kerugian) yang berbeda dengan pembiayaan (finansial) sistem bunga pada 
dunia perbankan konvensional yang semua resikonya ditanggung oleh pihak peminjam (debitur). (Muhammad Nejatullah Siddiqi, 1985: 9)

Menurut perniagaan Islam, kemitraan dan semua bentuk organisasi bisnis lainnya didirikan terutama dengan satu tujuan pembagian keuntungan melalui partisipasi bersama. Mudharabah dan musyarakah adalah dua model profit sharing ( bagi hasil) yang lebih disukai dalam hukum Islam, dan diantara kedua model ini maka mudharabah adalah model PLS yang paling umum digunakan (paling tidak dari segi peningkatan dana). Mudarabah dapat didefinisikan sebagai sebuah perjanjian diantara paling sedikit dua pihak dimana satu pihak, pemilik modal (shahib al-mal atau rabb al-mal) mempercayakan sejumlah dana kepada pihak lain, pengusaha (mudharib), untuk menjalankan suatu aktivitas atau usaha. (Abdullah Saeed, 1996: 65) Sedangkan musyarakah (dari kata arab syirkah atau syirikah) berarti suatu bentuk kemitraan dimana dua orang atau lebih menggabungkan modal atau kerja mereka untuk berbagi keuntungan, menikmati hak-hak dan tanggung jawab bersama.(Abdullah Saeed, 1996: 66)
Setiap transaksi yang dilakukan oleh bank syariah diwujudkan dalam bentuk tertulis yaitu perjanjian, perjanjian yang dibuat antara bank dengan nasabah dalam bentuk perjanjian baku. Macammacam perjanjian di bank syariah yang tidak dikenal dalam sistem hukum dan praktek hukum di Indonesia, hal ini merupakan pengembangan dari prinsip kebebasaan berkontrak. Padanan kata perjanjian dalam bahasa arab ialah aqad. Dalam istilah fiqih secara umum akad berarti sesuatu yang menjadi tekad seseorang untuk melaksanakan, baik yang muncul dari satu pihak seperti wakaf, talak, dan sumpah, maupun yang muncul dari dua pihak seperti jual beli, sewa, wakalah dan gadai. (Ascarya, 2007: 35). Secara khusus Aqad yaitu suatu perekatan antara ijab dan kabul dengan cara yang dibenarkan syariah yang berakibat adanya akibat hukum pada objeknya. ljab adalah pernyataan pihak pertama mengenai isi perikatan yang diinginkan, sedangkan kabul adalah pernyataan pihak kedua untuk menerimanya. Suatu akad-kontrak atau perjanjian dalam Hukum Islam-sah apabila memenuhi rukun dan syaratsyarat. Rukun adalah sesuatu yang harus ada dalam kontrak. Sedang syarat adalah 
PERSPEKTIF Volume XI No.3 Tahun 2006 Edisi Juli

persyaratan yang harus dipenuhi oleh rukun-rukun tersebut

Bank syariah dalam menjalankan kegiatannya harus berdasarkan prinsip kehatian-hatian sebagaimana diamanatkan pada Pasal 4 Undang-undang Perbankan Syariah, yang perwujudannya diatur dalam rambu-rambu kesehatan diatur pada Pasal 23. Pada Pasal 23 (1) Undang-Undang Perbankan syariah mengatur bahwa "Bank syariah dan/atau UUS harus mempunyai keyakinan atas kemauan dan kemampuan calon nasabah Penerima Fasilitas untuk melunasi seluruh kewajiban pada waktunya, sebelum Bank Syariah dan/atau UUS menyalurkan dana kepada nasabah Penerima Fasilitas". Untuk mendapatkan keyakinan maka bank syariah wajib melakukan penilaian yang seksama terhadap waktak, kemampuan, modal, agunan, dan prospek usaha dari calon nasabah penerima fasilitas (character, capacity, capital, collateral, condition). Pada Pasal 29 ayat (3) Undang-Undang Perbankan diatur bahwa "Dalam memberikan kredit atau pembiayaan berdasarkan prinsip syariah dan melakukan kegiatan usaha lainnya, Bank wajib menempuh cara-cara yang tidak merugikan bank dan kepentingan nasabah yang mempercayakan dananya kepada Bank. diperjanjikan". Sehingga bank syariah dalam memberikan pembiayaan wajib mempunyai keyakinan atas kemauan dan kemampuan dari nasabah penerima fasilitas.

$$
\text { Sebagian besar dana yang }
$$
dipergunakan oleh bank syariah dalam menyalurkan dana dalam bentuk pembiayaan adalah dana nasabah penyimpan/nasabah investor, sehingga dana nasabah penyimpan/nasabah investor wajib mendapat perlindungan hukum. Bilamana terjadi kegagalan dalam pembiayaan maka sumber pelunasan pembiayaan adalah dari usaha nasabah yang menghasilkan pendapatan (revenue) yang disebut first way out dan second way out berupa agunan (collateral). Second way out berupa jaminan tertentu atas suatu benda, apabila terjadi pembiayaan bermasalah, bank berhak menjual benda agunan yang dibebani dengan hak jaminan dan mengambil hasil penjualan atas benda tersebut sebagai sumber pelunasan pembiayaan. Jaminan merupakan hal penting untuk diperhitungkan bagi Bank karena jaminan merupakan sumber pelunasan bilamana nasabah mengalami kegagalan pembiayaan Syariah, meskipun pada 
perjanjian pembiayaan yang berdasarkan profit and loss sharing principle bank syariah tidak boleh meminta jaminan dari nasabah yang diberi pembiayaan.

Dengan kata lain bank hanya mengandalkan pendapatan dari bisnis nasabah yang dibiayai oleh bank syariah. Berdasarkan uraian di atas maka dapat dirumuskan permasalahan yaitu: Apa yang menjadi kriteria pembiayaan bermasalah di Bank Syariah dan upaya apa yang dilakukan oleh Bank Syariah dalam penanganan pembiayaan Bermasalah.

\section{Kebijakan Umum Penanaman Dana}

Semua bank wajib memiliki kebijakan umum penanaman dana secara tertulis, definisi penanaman dana adalah penyediaan dana, dan/atau barang serta fasilitas lainnya kepada nasabah, yang tidak bertentangan dengan konsep syariah dan standar akuntasi perbankan Islam yang berlaku. Penanaman dana pada bank syariah berupa pembiayaan. Pembiayaan adalah merupakan sebagian besar asset dari bank syariah sehingga pembiayaan tersebut harus dijaga kualitasnya, sebagaimana diamanatkan pada Pasal 2 Undang-undang Perbankan Syariah bahwa perbankan syariah dalam melakukan kegiatan usahanya berasaskan prinsip syariah, demokrasi ekonomi dan prinsip kehati-hatian. Penerapan prinsip kehati-hatian dijabarkan dalam bentuk rambu-rambu kesehatan bank.

Menurut Sutan Remy Sjahdeini diabaikannya rambu-rambu kesehatan bank oleh bank yang melakukan kegiatan berdasarkan prinsip syariah memberikan dampak kerugian yang jauh lebih besar daripada hal itu dilakukan oleh suatu bank konvensional. Paling sedikit ada dua alasan mengapa dampak tersebut lebih besar. Alasan pertama ialah karena resiko yang dihadapi oleh bank syariah dalam hal pembiayaan diberikan berdasarkan akad mudharabah kepada nasabahnya jauh lebih besar daripada risiko yang dihadapi oleh bank konvensional yang memberikan kredit dengan jaminan. Pada pembiayaan mudharabah bank syariah sebagai prinsip syariah tidak boleh meminta agunan dari nasabah yang diberi pembiayaan. Dengan kata lain bank syariah semata-mata hanya mengandalkan first way out. Alasan kedua, apabila terjadi kegagalan pada pembiayaan yang diberikan oleh bank syariah, antara lain dalam bentuk mudharabah dan musyarakah, nasabah tidak berkewajiban untuk mengembalikan 
dana tersebut. (Sutan Remy Sjadeini, 1999: 172)

Adapun tujuan dari diberlakukannya prinsip kehati-hatian tidak lain agar bank-bank selalu dalam keadaan sehat, sehingga antara lain selalu dalam keadaan likuid, solvent dan menguntungkan (profitable). Dengan diberlakukannya prinsip kehati-hatian itu diharapkan kadar kepercayaan masyarakat terhadap perbakan selalu tinggi sehingga masyarakat bersedia dan tidak ragu-ragu menyimpan dananya di bank. Suatu bank dapat hidup dan berkembang bergantung pada kemampuan bank mengerahkan dana dari masyarakat. Kemampuan mengerah-kan dana berupa simpanan masyarakat sangat bergantung pada tingkat kepercayaan masyarakat pada bank tersebut. sebagaimana diketahui bahwa perbankan syariah berfungsi sama dengan perbankan konvensional yaitu sebagai lembaga intermediasi yaitu berfungsi sebagai penghimpun dana masyarakat dan penyalur dana masyarakat.

Untuk menjaga kepercayaan masyarakat maka bank syariah dalam menyalurkan dananya dalam bentuk pembiayaan harus mengacu pada Kebijakan Umum Penanaman Dana
(KUPD), pembiayaan yang harus dihindari yaitu pembiayaan yang tidak sesuai dengan syariah (mengandung unsur masyir, gharar dan riba), pembiayaan untuk spekulasi, pembiayaan tanpa informasi keuangan yang tidak memadai, kecuali untuk pembiayaan yang jumlahnya relatif kecil dapat disesuaikan seperlunya, pembiayaan pada sektor usaha yang tidak dikuasai oleh sumber daya manusia bank, pembiayaan kepada nasabah bermasalah pada bank lain, pembiayaan yang lebih banyak mendatangkan mudharot daripada manfaat, pembiayaan yang menurut analisa termasuk beresiko tinggi, yang pada waktunya dapat menjadi pembiayaan bermasalah.

Pembiayaan merupakan kegiatan perbankan syariah yang sangat penting dan menjadi penunjang kelangsungan hidup bank syariah jika dikelola dengan baik, pengelolaan pembiayaan yang tidak baik akan banyak menimbulkan masalah bahkan akan menyebabkan ambruknya bank syariah. Dana masyarakat selayaknya disalurkan untuk keperluan pembiayaan yang produktif yaitu dalam bentuk pembiayaan dengan memperhatikan kaidah-kaidah aman, lancar dan menghasilkan. Ada beberapa pendekatan analisis pembiayaan yang dilakukan oleh 
PERSPEKTIF Volume XI No.3 Tahun 2006 Edisi Juli

pengelola bank syariah yaitu pendekatan jaminan, artinya bank dalam memberikan pembiayaan selalu memperhatikan kuantitas dan kualitas jaminan yang dimiliki oleh peminjam, pendekatan karakter, artinya bank mencermati secara sungguh-sungguh terkait dengan karakter nasabah, pendekatan kemampuan pelunasan artinya bank menganalisis kemampuan nasabah untuk melunasi jumlah pembiayaan yang diambil, pendekatan dengan studi kelayakan artinya bank memperhatikan kelayakan usaha yang dijalankan oleh nasabah peminjam, pendekatan fungsifungsi bank artinya bank memperhatikan fungsinya sebagai lembaga intermediary keuangan yaitu mengatur mekanisme dana yang dikumpulkan dengan dana yang disalurkan. (Muhammad, 2002: 260)

Demikian juga menurut Sutan Remy Sjahdeini bahwa Analisa pembiayaan diperlukan agar bank syariah memperoleh keyakinan bahwa pembiayaan yang diberikan dapat dikembalikan oleh nasabah.(Sutan Remy Sjadeini, 1999: 175). Pada dasarnya ada 2 (dua) aspek yang dianalisa yaitu analisa terhadap kemauan membayar disebut analisa kualitatif (willingnes to repay).
Aspek yang dianalisa mencakup karakter dan komitmen nasabah dan analisa terhadap kemampuan membayar disebit analisa kualitatif (ability to repay). Pendekatan yang digunakan adalah menentukan kemampuan bayar dan perhitungan kebutuhan modal usaha nasabah adalah dengan pendekatan pendapatan bersih.

Untuk mengetahui bagaimana kemauan dan kemampuan nasabah untuk memenuhi kewajibannya, bank melakukan analisa terhadap $5 \mathrm{C}$, yaitu character artinya sifat atau karakter nasabah pengambil pinjaman, Capacity artinya kemampuan nasabah untuk menjalankan usaha dan mengembalikan pinjaman yang diambil, Capital artinya besarnya modal yang diperlukan peminjam, Collateral artinya jaminan yang telah dimiliki yang diberikan peminjam kepada bank, Condition artinya keadaan usaha atau nasabah prospek atau tidak dan terkadang ditambah dengan $1 \mathrm{C}$ yaitu Constrain artinya hambatan-hambatan yang mungkin menganggu proses usaha. ( $\mathrm{M} \mathrm{uh}$ a m m a d, $2002: 261$ ) Pada pasal 23 Undang-undang Perbankan Syariah bank syariah dan/atau UUS harus mempunyai keyakinan atas kemauan dan kemampuan calon nasabah 
PERSPEKTIF Volume XI No.3 Tahun 2006 Edisi Juli

peneirma fasilitas untuk melunasi seluruh kewajiban pada waktunya, sebelum bank syariah dan/atau UUS menyalurkan dana kepada nasabah penerima fasilitas. Untuk memperoleh keyakinan maka bank syariah dan/atau UUS wajib melakukan penilaian yang seksama terhadap watak,kemampuan,modal, agunan dan prospek usaha dari calon nasabah penerima fasilitas.

Bank syariah tidak mengunakan metoda pinjam meminjam uang dalam rangka kegiatan komersial karena setiap pinjam meminjam uang dilakukan dengan persyaratan atau janji pemberian imbalan adalah termasuk riba, oleh karena itu mekanisme operasional perbankan syariah terlihat pada produk dan jasajasanya yang berdasarkan pada prinsipprinsip berikut Prinsip Bagi Hasil (profit and loss sharing), ada dua macam kontrak dalam kategori ini yaitu musyarakah (joint venture sharing) dan mudharabah (trustee profit sharing), Prinsip Jual Beli ( Al Bai), Al Murabaha, Bai' Al Salam dan Bai' Al Istishna, Prinsip Sewa dan Sewa Beli, Prinsip Qard, Prinsip Al Wadiah (titipan), Prinsip rahn, prinsip wakalah, prinsip kafalah, prinsip hawalah, prinsip ju'alah, prinsip sharf. (Zainul Arifin, 2000: 69-73)

Restrukturisasi Pembiayaan Sebagai Upaya Penyelamatan Pembiayaan Bermasalah
Bank syariah melakukan pula fungsi sosial (charity/ta'awwuh) yang biasanya tidak dilakukan oleh bank konvensional, karena orientasinya yang profit oriented. Misalnya dalam bank syariah memberikan fasilitas pembiayaan yang disebut Al Qardhul Hasan yaitu pinjaman uang tanpa imbalan apapun dan hanya dikembalikan dalam jumlah yang sama dengan jumlahnya pada waktu dipinjamkan. Kegiatan bank syariah tidak berkaitan erat dengan ritual keagamaan dari agama Islam, oleh karena itu bank syariah boleh memberikan fasilitas pembiayaan atau jasa-jasa perbankan kepada nasabah non muslim, dan bank syariah boleh dimiliki dan dikelola oleh mereka yang non muslim. Pada saat ini negara Amerika dan Eropa banyak memiliki Islamic Window, dengan kata lain juga melakukan kegiatan uasaha perbankan syariah di samping usaha perbankan konvensional. (Sutan Remy Sjadeini, 1999: 2-3)

Bisnis adalah suatu aktivitas yang selalu berhadapan dengan risiko dan return, bank syariah adalah suatu unit bisnis, sehingga bank syariah juga akan menghadapi risiko manajemen bank. bermasalah tetapi usaha nasabah penerima fasilitas masih memiliki prospek 
sehingga pembiayaan yang bermasalah itu dapat diselamatkan untuk menjadi lancar kembali. Tahap ini disebut tahap penyelamatan pembiayaan. (5) tahap setelah pembiayaan menjadi macet. Tahap ini disebut tahap penyelesaian pembiayaan

\section{Kriteria Pembiayaan Bermasalah}

Pembiayaan yang telah disetujui oleh bank syariah dan dinikmati oleh nasabah, maka peranan bank syariah lebih berat dibandingkan pada saat dana tersebut belum mengucur di tangan nasabah. Untuk menghindari terjadinya kegagalan pembiayaan maka bank syariah harus melakukan pembinaan dan regular monitoring yaitu dengan cara monitoring aktif dan monitoring pasif. Monitoring aktif yaitu mengunjungi nasabah secara regular, memantau laporan keuangan secara rutin dan memberikan laporan kunjungan nasabah/call report kepada komite pembiayaan/supervisor sedangkan monitoring pasif yaitu memonitoring pembayaran kewajiban nasabah kepada bank syariah setiap akhir bulan. Bersamaan pula diberikan pembinaaan dengan memberikan saran, informasi maupun pembinaan tehnis yang bertujuan untuk menghindari kegagalan pembiayaan.

Khususnya pada pembiayaan mudharabah dan musyarakah, bank syariah akan melakukan pengawasan dan pembinaan perkembangan proyek usaha yang dikelola oleh nasabah lebih ketat karena keuntungan yang akan diperoleh bank syariah berasal dari keuntungan yang dibagihasilkan berdasarkan nisbah yang telah disepakati bersama dari usaha yang dikelola oleh nasabah, sehingga jika usaha yang dikelola oleh nasabah tersebut gagal maka bank syariah harus memikul risiko kehilangan dana yang telah diberikan kepada nasabah.

Pada jangka waktu (masa) pembiayaan tidak mustahil terjadi suatu kondisi pembiayaan yaitu adanya suatu penyimpangan utama dalam hal pembayaran yang menyebabkan keterlambatan dalam pembayaran atau diperlukan tindakan yuridis dalam pengembalian atau kemingkinan potensial loss. Kondisi ini yang disebut dengan pembiayaan bermasalah, keadaan turunya mutu pembiayaan tidak terjadi secara tiba-tiba akan tetapi selalu memberikan "warning sign" atau faktorfaktor penyebab terlebih dahulu dalam 
Bahkan kalau dicermati mendalam bank syariah merupakan bank yang sarat ngka memperoleh keuntungan yang optimal.

Bahkan kalau dicermati mendalam bank syariah merupakan bank yang sarat risiko, karena dalam menjalankan aktivitasnya banyak berhubungan dengan produk-produk bank yang banyak mengadung risiko. Seperti pembiayaan dengan berdasarkan prinsip bagi hasil seperti mudharabah dan musyarakah. Risiko yang dihadapi oleh bank syariah adalah karena ketidakjujuran atau kecurangan nasabah dalam melakukan transaksi, oleh karena itu bank syariah harus dapat mengendalikan risiko seminimal mungkin dalam rangka memperoleh keuntungan yang optimal.

Pembiayaan adalah suatu proses mulai dari analisis kelayakan pembiayaan sampai kepada realisasinya. Namun realisasi pembiayaan bukanlah tahap terakhir dari proses pembiayaan. Setelah realisasi pembiayaan maka bank syariah perlu melakukan pemantauan dan pengawasan pembiayaan, karena dalam jangka waktu pembiayaan tidak mustahil terjadi pembiayaan bermasalah dikarenakan beberapa alasan. Bank syariah harus mampu menganalisis penyebab pembiayaan bermasalah sehingga dapat -melakukan upaya untuk melancarkan kembali kualitas pembiayaan tersebut. Proses pemberian pembiayaan pada bank syariah, tahapan yang dilakukan oleh bank syariah tidak jauh berbeda dengan tahapan yang dilakukan oleh bank konvensional dalam memberikan kreditnya. Proses pemberian pembiayaan diawali dengan tahapan yaitu: (1) tahap sebelum pemberian pembiayaan diputuskan oleh bank syariah, yaitu tahap bank syariah mempertimbangkan permohonan pembiayaan calon nasabah penerima fasilitas. Tahap ini disebut tahap analisis kelayakan penyaluran dana. (2) tahap setelah permohonan pembiayaan diputuskan pemberiannya oleh bank syariah dan kemudian penuangan keputusan tersebut kedalam perjanjian pembiayaan (akad pembiayaan) serta dilaksanakannya pengikatan agunan untuk pembiayaan yang diberikan itu. Tahap ini disebut tahap dokumentasi pembiayaan. (3) tahap setelah perjanjian pembiayaan (akad pembiayaan) ditandatangani oleh keduabelah pihak dan dokumentasi pengikatan agunan telah selesai dibuat serta selama pembiayaan itu digunakan oleh nasabah penerima fasilitas sampai jangka waktu pembiayaan berakhir. Tahap ini disebut 
PERSPEKTIF Volume XI No.3 Tahun 2006 Edisi Juli

masa pembiayaan.

Ada beberapa faktor penyebab pembiayaan bermasalah, yang disebabkan faktor intern (berasal dari pihak bank), dan faktor ekstern. Faktor intern misalnya kurang baiknya pemahaman atas bisnis nasabah, kurang dilakukan evaluasi keuangan nasabah, kesalahan setting fasilitas pembiayaan (berpeluang melakukan sidestreaming), perhitungan modal kerja tidak didasarkan kepada bisnis usaha nasabah, proyeksi penjualan terlalu optimis, proyeksi penjualan tidak memperhitungkan kebiasaan bisnis dan kurang memperhitungkan aspek kompetitor, aspek jaminan tidak diperhitungkan aspek marketable, lemahnya supervisi dan monitoring, terjadinya erosi mental: kondisi ini dipengaruhi timbali balik antara nasabah dengan pejabat bank sehingga mengakibatkan proses pemberian pembiayaan tidak didasarkan pada praktek perbankan yang sehat.

Sedangkan faktor ekstern misalnya disebabkan karena karakter nasabah tidak amanah (tidak jujur dalam memberikan informasi dan laporan tentang kegiatannya), melakukan sidestreaming penggunaan dana, kemampuan pengelolaan nasabah tidak memadai sehingga kalah dalam persaingan usaha, usaha yang dijalankan relatif baru, bidang usaha nasabah telah jenuh, tidak mampu menanggulangi masalah/kurang menguasai bisnis, meninggalnya key person, perselisihan sesama direksi, terjadi bencana alam, adanya kebijakan pemerintah: peraturan suatu produk atau sektor ekonomi atau industri dapat berdampak positif maupun negatif bagi perusahaan yang berkaitan dengan industri tersebut.

Pembiayaan yang diberikan oleh bank syariah merupakan salah satu bentuk dari aktiva produktif. Proses penentuan kualitas aktiva produktif melalui analisa serta evaluasi terhadap prospek usaha, kinerja (performance) nasabah dan kemampuan membayar untuk memenuhi kewajibannya adalah bertujuan untuk mendapatkan informasi sedini mungkin terhadap kondisi usaha nasabah serta kemampaun mereka mempertahankan usahanya sehingga dengan demikian manajamen bank dapat segera mengupayakan solusi yang tepat demi mengamankan dana masyarakat yang merupakan sumber pendanaan utama bank sekaligus kredibilitas bank dimata masyarakat luas, karena kegagalan bank dalam mengelola aktiva produktif sudah 
pasti akan berdampak yang sangat signifikan terhadap stabilitas perkonomian nasional. (Tim Kebijakan Perbankan Syariah Institut Bankir Indonesia, 2003: 259).

Kualitas pembiayaan ditetapkan menjadi 5 (lima) golongan yaitu Lancar, Dalam Perhatian Khusus, Kurang Lancar, Diragukan dan Macet, yang dikategorikan pembiayaan bermasalah adalah kualitas pembiayaan yang mulai masuk golongan Kurang lancar sampai golongan Macet sering disebut dengan pembiayaan tidak berprestasi ( Non Performance Financing/ NPF). Bank syariah wajib untuk menggolongkan kualitas aktiva produktif sesuai dengan kriterianya dan dinilai secara bulanan, sehingga jika bank syariah tidak melakukannya maka akan dikenakan sanksi administratif sebagaimana dimaksud Pasal 56 Undang-undang Perbankan Syariah.

Bilamana terjadi kegagalan pembiayaan maka Bank syariah akan melakukan upaya untuk menyelesaikan pembiayaan bermasalah tersebut, agar dana yang telah disalurkan oleh bank syariah dapat diterima kembali. Akan tetapi mengingat dana yang dipergunakan oleh bank syariah dalam mem-berikan pembiayaan berasal dari dana masyarakat yang ditempatkan pada bank syariah maka bank syariah dalam memberikan pembiayaan wajib menempuh cara-cara yang tidak merugikan bank syariah dan/atau UUS dan kepentingan nasabahnya yang telah mempercayakan dananya. Sebagaimana diatur pada Pasal 36 Undang-undang Perbankan Syariah.

Pada pembiayaan mudharabah bilamana kerugian dikarenakan dari risiko karakter buruk dari nasabah (character risk) misalnya nasabah lalai dan/atau melanggar persyaratan-persyaratan perjanjian mudharabah maka pemilik dana (shahibul maal/bank) tidak perlu menanggung kerugian seperti ini. Para fuqaha berpendapat bahwa pada prinsipnya tidak perlu dan tidak boleh mensyaratkan agunan sebagai jaminan. Sebagaimana dalam akad syirkah lainnya. Jelas hal ini dalam konteksnya adalah business risk. (Adiwarman Karim, 2007: 208). Jika nasabah (mudharib) melakukan keteledoran, kelalaian dan kecerobohan dalam merawat dan menjaga dana maka mudharib harus menanggung kerugian mudharabah sebesar bagian kelalaiannya sebagai 
sanksi dan tanggung jawabnya.

Untuk menghindari moral hazard dari pihak muharib yang lalai atau menyalahi kontrak maka pemilik dana (shahibul maal) dibolehkan meminta jaminan tertentu kepada mudharib. Jaminan ini akan disita oleh shaibul maal jika ternyata timbul kerugian karena mudharib melakukan kesalahan. Jadi tujuan penggenaan jaminan dalam akad mudaharabah adalah untuk menghindari moral hazard dari nasabah (mudharib) bukan untuk mengamankan nilai investasi jika terjadi kerugian karena faktor risiko bisnis. Tegasnya bila kerugian yang timbul disebabkan karena tidak dapat disita oleh shahibul maal. (Adiwarman Karim, 2007: 209)

Para ulama kontemporer berfatwa dan berpendapat tentang bolehnya bagi shahibul maal untuk meminta agunan dari amil berpijak pada kaedah ushul fiqh yaitu $A$ l mashaalih $A$ l mursakah yang mengacu pada kebutuhan, kepentingan, kebaikan dan kemaslahatan umum selama tidak bertentangan dengan prinsip dan dalil tegas syariat. Dan benar-benar membawa kepada kebaikan bersama yang tidak berdampak menyulitkan serta faktor risiko bisnis, jaminan mudharib

merugikan seorang atau pihak lain.(Muhammad, 2000: 59)

\section{Penanganan Pembiayaan Bermasalah}

Bank syariah dalam memberikan pembiayaan berharap bahwa pembiayaan tersebut berjalan dengan lancar, nasabah mematuhi apa yang telah disepakati dalam perjanjian dan membayar lunas bilamana jatuh tempo. Akan tetapi bisa terjadi dalam jangka waktu pembiayaan nasabah mengalami kesulitan dalam pembayaran yang berakibat kerugian bagi bank syariah.

Untuk menurunkan risiko dalam pembiayaan bank dapat melakukan langkah-langkah antisipatif untuk menjaga kelangsungan usaha nasabah pembiayaan. Langkah-langkah tersebut antara lain dengan melakukan restrukturisasi pembiayaan terhadap nasabah yang masih memiliki prospek usaha dan/atau kemampuan membayar. Penyelamatan pembiayaan berdasarkan PB I No.10/ 18/PBI/2008 tentang Restrukturisasi Pembiayaan Bagi Bank Syariah dan Unit Usaha Syariah maka bank syariah akan melakukan restrukturisasi pembiayaan, antara lain melalui: (a) Penjadwalan kembali (rescheduling), yaitu perubahan jadwal pembayaran kewajiban nasabah atau jangka waktunya, (b) Persyaratan kembali (reconditioning) yaitu perubahan 
PERSPEKTIF Volume XI No.3 Tahun 2006 Edisi Juli

sebagian atau seluruh persyaratan pembiayaan, antara lain perubahan jadwal pembayaran, jumlah angsuran, jangka waktu dan/atau pemberian potongan. sepanjang tidak menambah sisa kewajiban nasabah yang harus dibayarkan kepada bank, (c) Penataan kembali (restructuring) yaitu perubahan per-syaratan pembiayaan tidak terbatas pada rescheduling atau reconditioning, antara lain meliputi: Penambahan dana fasilitas pembiayaan bank, Konversi akad pembiayaan, Konversi pembiayaan menjadi surat berharga syariah berjangka waktu menengah, Konversi pembiayaan menjadi penyertaan modal sementara pada perusahaan nasabah .Bank hanya dapat melakukan restrukturisasi pembiayaan terhadap nasabah yang memenuhi kriteria sebagai berikut: (1) nasabah telah atau diperkirakan mengalami penurunan atau kesulitan kemampuan dalam pembayaran dan/ atau pemenuhan ke-wajibannya; dan (2) nasabah memiliki prospek usaha yang baik dan mampu memenuhi kewajiban setelah di-restrukturisasi..

Restrukturisasi pembiayaan hanya dapat dilakukan untuk pembiayaan dengan kualitas kurang lancar, diragukan dan macet. Dan dilakukan atas dasar permohonan secara tertulis dari nasabah. Pada Pasal 15 PBI No.10/18/PBI/2008 diatur tentang tatacara restrukturisasi pembiayaan. Pada pembiayaan dalam bentuk piutang murabaha atau piutang istishna dapat direstrukturisasi dengan cara: (a) penjadualan kembali (rescheduling); (b) persyaratan kembali (reconditioning); dan (c) penataan kembali (restructuring). Pembiayaan dalam bentuk piutang qardh dapat direstrukturisasi dengan cara : (a) Penjadualan kembali (rescheduling); dan (b) Persyaratan kembali (reconditioning). Pembiayaan dalam bentuk mudharabah atau musyarakah dapat direstrukturisasi dengan cara : (a) penjadualan kembali (rescheduling); (b) persyaratan kembali (reconditioning); dan (c) penataan kembali (restructuring). Pembiayaan dalam bentuk ijarah atau ijarah muntahiyah bittamlik dapat direstrukturisasi dengan cara: (a) penjadualan kembali (rescheduling); (b) persyaratan kembali (reconditioning); dan (c) penataan kembali (restructuring). Pembiayaan multijasa dalam bentuk ijarah dapat direstrukturisasi dengan cara: (a) penjadualan kembali (rescheduling); dan (b) persyaratan kembali (reconditioning). Pembiayaan dalam bentuk piutang salam dapat direstrukturisasi dengan cara : (a) 
penjadualan kembali (rescheduling); (b) persyaratan kembali (reconditioning); dan (c) penataan kembali (restructuring).

Berdasarkan Fatwa DSN No.19/DSNMUI/IV/2001 tentang Al Qardh pada pembiayaan AI Qardh, jika nasabah tidak mengembalikan sebagaian atau seluruh kewajibannya pada bank syariah pada saat yang telah disepakati dan bank syariah telah memastikan ketidakmampuannya, maka bank syariah dapat: (1) memperpanjang jangka waktu pengembalian, atau (2) menghapus (write off) sebagian atau seluruh kewajibannya.

Pada pembiayaan murabaha bank syariah dapat melakukan penjadwalan kembali (rescheduling) tagihan murabaha bagi nasabah yang tidak bisa menyelesaikan/melunasi pembiayaannya sesuai jumlah dan waktu yang telah disepakati dengan ketentuan: Tidak menambah jumlah tagihan yang tersisa; pembebanan biaya dalam proses penjadwalan kembali adalah biaya riil; perpanjangan masa pembayaran harus berdasarkan kesepakatan kedua belah pihak.

Memberikan potongan dari total kewajiban pembayaran dan konversi akad murabaha yang dilaksanakan sesuai dengan fatwa DSN yang berlaku. Pada fatwa DSN No.49/DSN-MUI/II/2005 tentang konversi akad murabahah, bahwa LKS dapat melakukan konversi dengan membuat akad baru bagi nasabah yang tidak bisa menyelesaikan/melunasi pembiayaan murabahanya sesuai jumlah dan waktu yang telah disepakati, tetapi ia masih prospektif dengan ketentuan: (a) akad murabaha dihentikan dengan cara: (i) obyek murabaha dijual oleh nasabah kepada LKS dengan harga pasar, (ii) Nasabah melunasi sisa hutangnya kepada LKS dari hasil penjualan. (iii) Apabila hasil penjualan melebihi sisa hutang, maka kelebihan itu dapat dijadikan uang muka untuk akad ijarah atau bagian modal dari mudharabah dan musyarakah. (iv) Apabila hasil penjualan lebih kecil dari sisa hutang maka sisa hutang tetap menjadi hutang nasabah yang cara pelunasannya disepakati antara LKS dengan nasabah.

Adapun landasan syariah yang mendukung upaya restrukturisasi pembiayaan: dalam surat Al Baqarah (2): 276: "Allah memusnahkan riba dan menyuburkan sedekah dan Allah tidak menyukai setiap orang yang tetap dalam kekafiran dan selalu berbuat dosa". Dalam surat Al Baqarah (2): 280: "dan jika (orang berhutang itu) dalam kesukaran, maka 
PERSPEKTIF Volume XI No.3 Tahun 2006 Edisi Juli

berilah tangguh sampai dia berkelapangan. Dan menyedekahkan (sebagian atau semua hutang) itu lebih baik bagimu, jika kamu mengetahui". Dalam surat Al Baqarah (2) : 286: "Allah tidak membebani seseorang melainkan sesuai dengan kesanggupannya. la mendapat pahala (atas kebajikan) yang diusahakannya dan ia mendapat siksa (dari kejahatan) yang dikerjakannya”. Dari kutipan ayatAI Quran diatas selalu digarisbawahi pentingnya sedekah dan tuntunan akan perlunya toleransi terhadap nasabah bila menghadapi nasabah sedang mengalami kesulitan (dalam arti sebenar-benarnya) membayar kembali kewajibannya.

Hadits Nabi riwayat Muslim :

" orang yang melepaskan seorang muslim dari kesulitannya di dunia, Allah akan melepaskan kesulitannya di hari kiamat; dan Allah senantiasa menolong hamba-Nya selama ia (suka) menolong saudaranya".

Upaya restrukturisasi merupakan upaya penyelamatan pembiayaan bermasalah yang dilakukan oleh bank syariah, bilamana upaya tersebut tidak memulihkan kembali pembiayaan bermasalah maka upaya alternatif yang dilakukan oleh bank syariah adalah :
- Penyelesaian melalui jaminan

Penyelesaian melalui jaminan dilakukan oleh bank syariah bilamana berdasarkan evaluasi ulang pembiayaan, prospek usaha nasabah tidak ada dan atau nasabah tidak kooperatif untuk menyelesaikan pembiayaan. Eksekusi jaminan disesuaikan dengan lembaga jaminan yang membebani benda jaminan tersebut, rahn (gadai syariah),jaminan hipotik, jaminan hak tanggungan, dan jaminan fidusia. pada jaminan hipotik eksekusi agunan diatur pada Pasal 1178 BW, Pada jaminan hak tanggungan berdasarkan Pasal 20 Undang-undang No.4 Tahun 1996, bilamana debitor cidera janji ada 3 alternatif yang dapat dilakukan oleh bank yaitu: berdasarkan hak pemegang hak tanggungan pertama untuk menjual obyek hak tanggungan sebagaimana dimaksud dalam Pasal 6 atau berdasarkan titel eksekutorial yang terdapat dalam sertifikat hak tanggungan sebagaimana pada Pasal 14 (2) obyek hak tanggungan dijual melalui pelelangan umum menurut tatacara yang ditentukan dalam peraturan perundnag-undangan untuk pelunasan piutang pemegang hak tanggungan dengan hak mendahulu dari 
para kreditor-kreditor lainnya atas kesepakatan penjualan obyek jaminan dapat dilaksanakan dibawah tangan jika dengan cara demikian akan dapat diperoleh harga tertinggi.

Pada jaminan fidusia berdasarkan Pasal 29 Undang-undang Nomor 42 Tahun 1999 apabila debitor wanprestasi maka obyek jaminan dapat dieksekusi dengan cara: (a) pelaksanaan titel eksekutorial, (b) penjualan benda yang menjadi obyek jaminan fidusia atas kekuasaan penerima fidusia sendiri melalui pelelangan umum, (c) penjualan dibawah tangan berdasarkan kesepakatan. Di Undang-undang Perbankan Syariah pada Pasal 40, bank syariah dan UUS dapat membeli sebagian atau seluruh agunan, baik melalui maupun di luar pelelangan, berdasarkan penyerahan secara sukarela oleh pemilik agunan atau berdasarkan pemberian kuasa untuk menjual dari pemilik agunan, dengan ketentuan agunan yang dibeli tersebut wajib dicairkan selambat-lambatnya dalam jangka waktu 1 (satu) tahun. Dalam hal harga pembelian agunan melebihi jumlah kewajiban nasabah kepada bank syariah dan UUS, selisih kelebihan jumlah tersebut harus dikembalikan kepada nasabah setelah dikurangi dengan biaya lelang dan biaya lain yang terkait langsung dengan proses pembelian agunan.

Landasan syariah yang berkaitan dengan jaminan dalam surat Al Baqarah (2) 283: "Jika kamu dalam perjalanan (dan kamu bermuamalah/ jual beli tidak secara tunai), sedang kamu tidak memperoleh seorang penulis, maka hendaklah ada barang tanggungan yang dipegang oleh siberpiutang..."

Dari Aisyah bahwasanya Nabi Muhammad SAW pernah membeli bahan makanan dari seorang yahudi dengan hutang dan beliau memberikan baju besinya sebagai jaminan (HR.Bukhari, Muslim dan Nasa'i). Dari Abu Hurairah r.a. bahwa Rasulullah bersabda "Siapapun yang bangkrut (muflis), lalu kreditornya mendapatkan barangnya sendiri pada si muflis, maka kreditor itu lebih berhak untuk menarik kembali barangnya daripada orang lain. (HR.Bukhari, Muslim, Tirmidzi, Nasa'i dan Ibnu Majah)

- Penyelesaian lewat Badan Arbitrase Syariah Nasional

Berdasarkan klausula dalam perjanjian pembiayaan, bilamana jika salah satu pihak tidak menunaikan 
PERSPEKTIF Volume XI No.3 Tahun 2006 Edisi Juli

kewajibannya atau terjadi perselisihan diantara kedua belah pihak dan tidak tercapai kesepakatan melalui musyawarah, maka penyelesainya melalui Badan Arbitrase Syariah Nasional (BASYARNAS). Keputusan arbitrase merupakan keputusan terakhir dan mengikat (final and biding), akan tetapi penyelesaian lewat BASYARNAS jarang dilakukan oleh bank syariah untuk menyelesaiakan sengketa sehingga nampak peran BASYARNAS kurang berperan didalam menyelesaikan sengketa.

\section{- $\quad$ Penyelesaian lewat litigasi}

Penyelesaian lewat litigasi akan ditempuh oleh bank bilamana nasabah tidak beritkad baik yaitu tidak menunjukkan kemauan untuk memenuhi kewajibannya sedangkan nasabah sebenarnya masih mempunyai harta kekayaan lain yang tidak dikuasai oleh bank atau sengaja disembunyikan atau mempunyai sumber-sumber lain untuk menyelesaikan kredit macetnya.(Sutan Remy Sjadeini,1999: 103) Sejak diundangkannya Undang-undang Nomor 3 tahun 2006 tentang Peradilan Agama maka bilamana terjadi sengketa dalam bidang muamalah maka diselesaikan lewat pengadilan agama. Tujuan dari keberadaan Peradilan Agama adalah bertugas dan berwenang memeriksa, memutus dan menyelesaikan perkara di tingkat pertama antara orang-orang beragama Islam dibidang : perkawinan, waris, wasiat, hibah, waqaf, zakat, infaq, shadaqoh dan ekonomi syariah.

Perubahan penting yang terdapat dalam Undang-undang Nomor 3 Tahun 2006 adalah perluasan kekuasaan atau kewenangan pengadilan agama yang meliputi juga sengketa di bidang ekonomi syariah, hal ini terdapat pada Pasal 49 Undang-undang Nomor 3 Tahun 2006. yang dimaksud dengan ekonomi syariah adalah perbuatan atau kegiatan usaha yang dilaksanakan menurut syariah, meliputi: Bank Syariah, Asuransi Syariah, Reasuransi Syariah, Reksa Dana Syariah, Obligasi Syariah dan surat berharga berjangka menengah syariah, Sekuritas Syariah, Pembiayaan Syariah, Pegadaian Syariah, Dana Pensiun lembaga Keuangan Syariah, Bisnis Syariah dan Lembaga Keuangan Mikro Syariah.

Sebelum diberlakunya Undangundang Nomor 3 Tahun 2006, sengketa ekonomi syariah tidak dapat diselesaikan di pengadilan agama, karena wewenang 
pengadilan agama dibatasi oleh Undangundang Nomor 7 Tahun 1989 yang hanya dapat memeriksa, memutus dan menyelesaiakan perkara-perkara yang menyangkut perkawinan, warisan, wasiat, hibah, waqaf dan shadaqoh. Artinya pengadilan agama tidak dapat memeriksa, memutus dan menyelesaikan perkara-perkara diluar keenam bidang tersebut. Sehingga apabila ada sengketa ekonomi syariah para pihak dapat menyelesaikan di pengadilan negeri (jalur litigasi) atau di Badan Arbitrase Syariah (jalur non litigasi). Kewenangan Pengadilan Agama yang dipaparkan oleh Undang-undang No. 3 Tahun 2006 ini memberikan kejelasan dan kepastian bagi masyarakat maupun pelaku ekonomi syariah.

\section{- Hapus Buku dan Hapus Tagih}

Hapus buku adalah tindakan administrstif bank untuk menghapus buku pembiayaan yang memiliki kualitas macet dari neraca sebesar kewajiban nasabah tanpa menghapus hak tagih bank kepada nasabah. Hapus tagih adalah tindakan bank menghapus kewajiban nasabah yang tidak dapat diselesaikan, dalam arti kewajiban nasabah dihapuskan tidak tertagih kembali. Hapus tagih merupakan salah satu cara dari hapusnya perikatan sebagaimana diatur pada Pasal 1318 BW. Hapus buku dan hapus tagih hanya dapat dilakukan terhadap pembiayaan yang memiliki kualitas macet. Hapus buku tidak dapat dilakukan terhadap sebagian pembiayaan (partial write off) sedangkan hapus tagih dapat dilakukan baik untuk sebagian atau seluruh pembiayaan. Hapus tagih terhadap sebagian pembiayaan hanya dapat dilakukan dalam rangka restrukturisasi pembiayaan atau dalam rangka penyelesaian pembiayaan. Hapus buku dan/atau hapus hanya dapat dilakukan setelah bank syariah melakukan berbagai upaya untuk memperoleh kembali aktiva produktif yang diberikan.

\section{PENUTUP}

Pembiayaan adalah merupakan sebagian besar asset dari bank syariah sehingga pembiayaan tersebut harus dijaga kualitasnya. Bank syariah dan/atau UUS harus mempunyai keyakinan atas kemauan dan kemampuan calon nasabah Penerima Fasilitas untuk melunasi seluruh kewajiban pada waktunya, 
PERSPEKTIF Volume XI No.3 Tahun 2006 Edisi Juli

sebelum Bank Syariah dan/atau UUS menyalurkan dana kepada nasabah Penerima Fasilitas". Untuk mendapatkan keyakinan maka bank syariah wajib melakukan penilaian yang seksama terhadap waktak, kemampuan, modal, agunan, dan prospek usaha dari calon nasabah penerima fasilitas (character, capacity, capital, collateral, condition). Pembiayaan yang diberikan oleh bank syariah selalu mengandung risiko yaitu terjadinya kegagalan pembiayaan sehingga timbul pembiayaan bermasalah (Non Performing Financing) yaitu pembiayaan dalam kategori kurang lancar, diragukan dan macet. Pada pembiayaan bermasalah maka bank syariah akan berupaya untuk menyelamatkan pembiayaan dengan melakukan restrukturisasi pembiayaan, yaitu dengan: Penjadwalan kembali (rescheduling), yaitu perubahan jadwal pembayaran kewajiban nasabah atau jangka waktunya. Persyaratan kembali (reconditioning) yaitu perubahan sebagian atau seluruh persyaratan pembiayaan, antara lain perubahan jadwal pembayaran, jumlah angsuran, jangka waktu dan/atau pemberian potongan. sepanjang tidak menambah sisa kewajiban nasabah yang harus dibayarkan kepada bank. Penataan kembali (restructuring) yaitu perubahan persyaratan pembiayaan tidak terbatas pada rescheduling atau reconditioning, antara lain meliputi : (a) Penambahan dana fasilitas pembiayaan bank, (b) Konversi akad pembiayaan, (c) Konversi pembiayaan menjadi surat berharga syariah berjangka waktu menengah, (d) Konversi pembiayaan menjadi penyertaan modal sementara pada perusahaan nasabah .

Bilamana upaya restrukturisasi yang dilakukan oleh bank syariah tidak dapat memulihkan kembali pembiayaan pada kategori lancar maka ada beberapa alternatif yang dilakukan oleh bank syariah untuk menyelesaikan pembiayaan bermasalah yaitu :Penyelesaian lewat jaminan, Penyelesaian lewat Basyarnas, Penyelesaian lewat litigasi, Hapus buku dan hapus tagih

\section{DAFTAR PUSTAKA}

Antonio, Muhammad Syafii, Bank Syariah Suatu Pengenalan Umum, Tazkia Institute, Jakarta, 2000

Abdullah Saeed, Islamic Banking and Interest a Study of The Prohibition of riba and Comtempory Intrepretation, E..J BRIIL-NEW 
PERSPEKTIF Volume XI No.3 Tahun 2006 Edisi Juli

YORK-KOLN, 1996

Ascarya, Akad dan Produk Bank Syariah,

RajaGrafindo Persada, Jakarta, 2007

Adiwarman A.Karim, Bank Islam Analisis

Fiqih dan Keuangan ,

RajaGrafindo Persada, Jakarta, 2007

Djumhana, Mohammad, Hukum

Perbankan di Indonesia, Citra Aditya, Jakarta, 1993

Mervyn Lewis, and Latifa Algaoud, Islamic Banking, Edward Elgar, Massachusetts,2001

Muhammad, Bank Syari'ah Problem Dan

Prospek Perkembangan di

Indonesia, Graha IImu, Yogyakarta, 2005

Muhammad, Manajemen Bank

Syariah, UPP AMP YKPN,

Yogjakarta, 2002

Muhammad, Tehnik Perhitungan Bagi Hasil di Bank Syariah, UII Press, Jogjakarta, 2000

Muhammad Nejatullah Siddiqi, , Partnership and Profit-Sharing in Islamic Law, Islamic Foudation, London, 1987

Sutan Remy Sjahdeini, Perbankan Islam dan Kedudukannya dalam Tata Hukum Perbankan Indonesia,
Pustaka Utama Grafiti, Jakarta, 1999

Tim Pengembangan Perbankan Syariah IBI, Konsep, Produk dan Implementasi Operasional Bank Syariah, Djambatan, Jakarta, 2001

II. Disertasi, Jurnal, Majalah, Makalah dan Karya IImiah Lainnya

Zainul Arifin," Produk Perbankan Syariah Dan Prospek Pasarnya di Indonesia, Jurnal Hukum Bisnis, Volume 20, Agustus-Septemebr, 2002, h.69-73

Sutan Remy Sjahdeini, Menyongsong RUU Perbankan Syariah", Jurnal Hukum Bisnis, Volume 20, Agustus-September, 2002

\section{Peraturan Perundang-undangan}

Undang-undang Nomor 7 Tahun 1992 Tentang Perbankan, LN RI Tahun 1992 Nomor 31

Undang-undang Nomor 10 Tahun 1998 Tentang Perubahan Undangundang Nomor 7 Undang-undang Nomor 7 Tahun 1992 tentang Perbankan , LN RI Tahun.1998 Nomor 182 
PERSPEKTIF Volume XI No.3 Tahun 2006 Edisi Juli

Undang-Undang Nomor 3 Tahun 2006

Tentang Perubahan Atas Undang-

Undang Nomor 7 Tahun 1989

Tentang Peradilan Agama, LN RI

Tahun 2006 Nomor 22

Undang-undang Nomor 21 Tahun 2008

Tentang Perbankan Syariah, LNRI Tahun 2008 Nomor 94

Peraturan Bank Indonesia Nomor 6/17/PBI/2004 Tentang Bank Perkreditan Rakyat Berdasarkan Prinsip Syaria
Peraturan Bank Indonedia Nomor 6/24/PBI/2004 Tentang Bank Umum Berdasarkan Prinsip Syariah

Peraturan Bank Indonesia Nomor 10/18/PBI/2008 Tentang Restrukturisasi Pembiayaan Bagi Bank Syariah dan Unit Usaha Syariah 